\title{
Single lung transplantation in a patient with retrospective positive cross-match
}

\author{
Anna Justyna Lesińska ${ }^{1}$, Maria Piotrowska ${ }^{2}$, Paweł Dec ${ }^{3}$, Piotr Wasilewski ${ }^{4}$, Anna Kubisa ${ }^{5}$, \\ Jarosław Pieróg ${ }^{2}$, Norbert Wójcik², Michalina Czarnecka², Bartosz Kubisa², Tomasz Grodzki² \\ ${ }^{1}$ Department of Interventional Cardiology, Provincial Hospital in Szczecin, Poland \\ ${ }^{2}$ Department of Thoracic Surgery and Transplantation, Pomeranian Medical University in Szczecin, Poland \\ ${ }^{3}$ Department of General Surgery and Hand Surgery, Pomeranian Medical University in Szczecin, Poland \\ ${ }^{4}$ Department of Intensive Care, A. Sokołowski Specialist Hospital in Szczecin, Poland \\ ${ }^{5}$ Department of Internal Medicine, A. Sokołowski Specialist Hospital in Szczecin, Poland
}

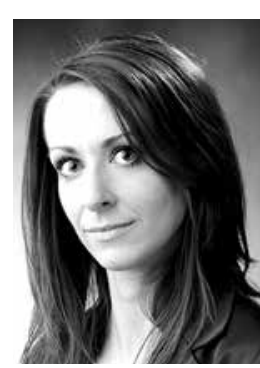

Kardiochirurgia i Torakochirurgia Polska 2015; 12 (1): 351-354

\begin{abstract}
Lung transplantation is a method useful in such non-malignant end-stage parenchymal and vascular diseases as: chronic obstructive pulmonary disease (COPD), idiopathic interstitial pulmonary fibrosis, cystic fibrosis, or primary pulmonary hypertension. The main aim of this procedure is to extend the patient's lifespan and quality of life. However, the availability of the operation is limited by organ access. In this paper we present the case of a 58-year-old female in the fourth stage of COPD, who was classified to have a single lung transplantation. Because of some technical problems it was decided to transplant a left donor lung in the right recipient lung locus. Positive cross match was demonstrated retrospectively, and we applied five courses of plasmapheresis. Human immunoglobulin and rituximab treatment were performed to decrease the impact of lymphocytotoxic antibodies. The patient survived 498 days after transplantation, 271 in the hospital.
\end{abstract}

Key words: lung transplantation, retrospective positive crossmatch.

\section{Introduction}

According to the statistical analysis of the International Society of Heart and Lung Transplantation, survival after lung transplantation systematically improves. $88 \%$ of recipients survive three months after operation, $79 \%$ survive for one year, and about $50-60 \%$ of recipients survive five years after transplantation. The most common indication for lung transplantation is chronic obstructive pulmonary disease (COPD) (34\%). Reoperation is needed in reference to $2.6 \%$ recipients. The major early causes of death are graft failure and non-CMV infections, bronchitis obliterans

\section{Streszczenie}

Transplantacja płuc jest metodą pozwalającą na leczenie pacjentów w przypadku takich jednostek chorobowych, jak przewlekła obturacyjna choroba płuc, śródmiąższowe idiopatyczne włóknienie płuc, mukowiscydoza i pierwotne nadciśnienie płucne. Głównym celem przeszczepienia płuc jest przedłużenie oraz poprawienie komfortu życia pacjentowi. Liczba operacji jest jednak ograniczona liczbą dostępnych do celów transplantacji narządów. W pracy przedstawiono przypadek 58-letniej chorej w stadium niewydolności oddechowej przewlekłej obturacyjnej choroby płuc, która została zakwalifikowana do przeszczepienia płuc. Z powodu trudności technicznych, śródoperacyjnie zadecydowano o wszczepieniu lewego płuca dawcy w miejsce prawego płuca biorcy. Retrospektywnie wykazano dodatnią próbę krzyżową, z powodu której przeprowadzono 5 zabiegów plazmaferezy oraz wdrożono leczenie ludzkimi immunoglobulinami i rituksymabem w celu eliminacji produkcji przeciwciał limfocytotoksycznych. Pacjentka po przeszczepie przeżyła 498 dni, w tym 271 w szpitalu.

Stowa kluczowe: przeszczepienie płuca, retrospektywnie dodatnia próba krzyżowa.

syndrome (BOS), chronic lung rejection, and graft failure after one year. Better results of lung transplantation occur when the operation is bilateral [1].

\section{Case report}

A 58-year-old female with hyperthyroidism, osteoporosis, and COPD in the fourth stage was classified for lung transplantation in 2011. Additional tests demonstrated $\mathrm{PaO}_{2}$ (partial pressure of oxygen) $61.2 \mathrm{mmHg}, \mathrm{PaCO}_{2}$ (partial pressure of carbon dioxide) $44 \mathrm{mmHg}$ (on oxygen therapy $2 \mathrm{l} / \mathrm{min}$ ), FEV $_{1}$ (forced expiratory volume in 1 second) 
0.44 I - 19.7\%sd, FVC (forced vital capacity) $1,38,8 \% \mathrm{sd}$, 6-MWT (six-minute walk test) 174 metres, RVSP (right ventricular systolic pressure) $36 \mathrm{mmHg}$, and PRA (panel reactive antibody) $3 \%$. After four months of expectation a 57 -yearold female donor, who died because of cerebral haemorrhage and was ventilated for 48 hours with $\mathrm{PaO}_{2} / \mathrm{FiO}_{2}$ $360 \mathrm{mmHg}$, was identified. Both women were characterised by comparable growth and identical blood group. The day after donor identification the transplantation was performed. For this purpose anterolateral thoracotomy in the fifth intercostal space and transverse sternotomy was performed. The right pulmonary vein cuff proved to be very short and tight, so it was decided to implant the left donor lung in the recipient's right emphysemal lung locus. Elements of the recipient's right lung hilum were dissected, cut distally with clamping of the pulmonary artery and pulmonary veins cuff. After preparation the left donor's lung was implanted in the contralateral position. In conjunction with different bronchus diameters the donor bronchus was telescopically placed in the recipient's bronchus and stitched with single absorbable sutures 3-0. The artery and vein were anastomosed with vascular suture 4-0. The pulmonary circulation was vented and restored, and the ventilation was resumed. After haemostasis was obtained the correct function of the graft was confirmed. Two drains were inserted in the pleural cavity, and closure of the thorax was carried out. Metal suturing of the sternum and the suturing of the periosteum of the fifth rib and layered lid suture were performed (Fig. 1). After operation the patient was transferred to the intensive

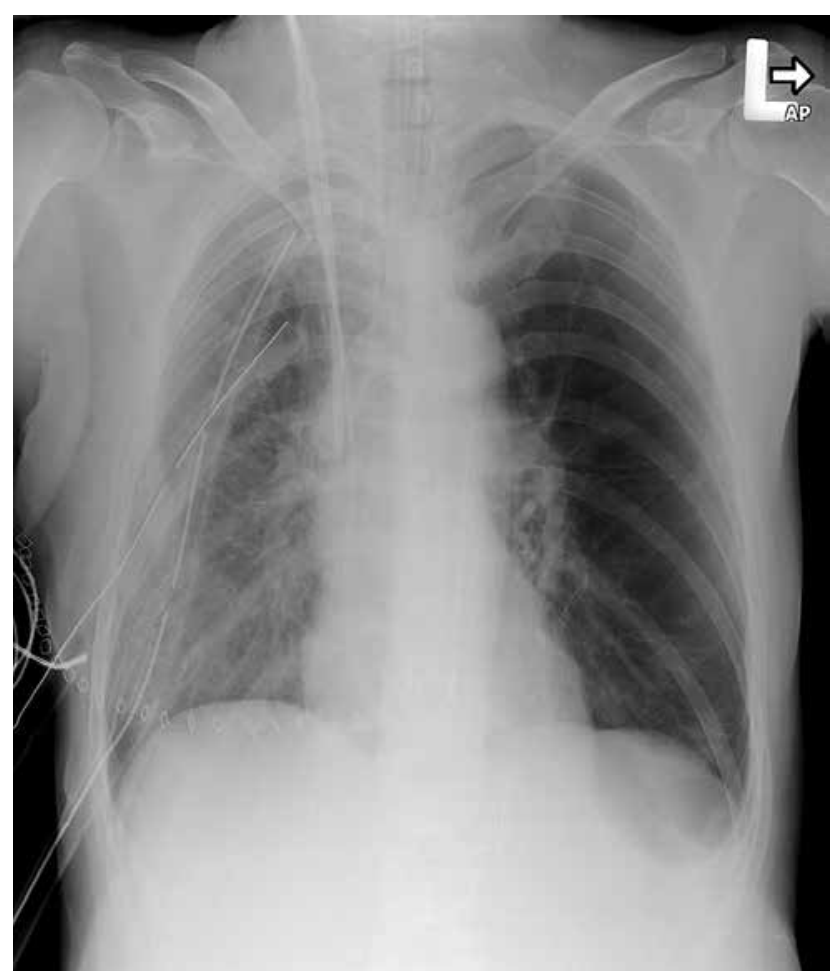

Fig. 1. Chest X-ray performed after transplantation. Two drains inserted in right pleural cavity and catheter in right carotid internal vein are visible care unit (ICU), where she stayed for eight days. Because of retrospectively positive cross-match it was necessary to implement five automatic plasmapheresis and to apply human immunoglobulin and rituximab to diminish concentration of lymphocytotoxic antibodies against HLA antigens. On the third day after transplantation the primary graft dysfunction and rising emphysema of the recipient's own lung shifted the mediastinum towards the graft side. As well as standard treatment, C1-esterase was provided to deplete the extracapillary exudation, and the operative (lung volume reduction surgery - LVRS) reduction of emphysemal changed lung tissue was pursued with complication of prolonged air leakage (Fig. 2). In ICU the patient needed infusion of 16 units of fresh frozen plasma (FFP), 2 units of packed red blood cells (PRBCs), and $100 \mathrm{ml}$ of $20 \%$ albumin. The right lung drainage was removed after seven days and the left one after 35 days. On the $44^{\text {th }}$ day after transplantation the patient was discharged from hospital with the following study results: $\mathrm{PO}_{2} 68.9 \mathrm{mmHg}, \mathrm{PCO}_{2}$ $44.0 \mathrm{mmHg}$ (without oxygen therapy), $\mathrm{FEV}_{1} 1.12-50.5 \%$, FVC 1.38-52.2\%, 6-MWT 246 metres, and with recommendation of taking immunosuppressing medications such as: $50 \mathrm{mg}$ of cyclosporine twice a day, $1000 \mathrm{mg}$ of mycophenolate mofetil twice a day, and $10 \mathrm{mg}$ of prednisone once a day. Four months after the operation the first acute organ rejection episode occurred (Fig. 3). It was histopathologically confirmed and antibodies against donor antigens were detected (anti-HLA class II 158.57-701.89 MFI). On the third day the therapy with methylprednisolone was pursued. In chronically treatment instead of cyclosporine the tacrolimus of $0.5 \mathrm{mg}$ a day was implemented. Additionally, the hospitalisation was complicated by Moraxella catarrhalis infection, so amoxicillin with clavulanic acid was applied. Diagnostic tests performed meanwhile showed transient renal failure, ion disorders, hypoproteinaemia, and leukopaenia. At the turn of fifth and sixth month after transplantation the next complications occurred: bronchitis caused by Corynebacterium pseudodiphtericum, and Escherichia

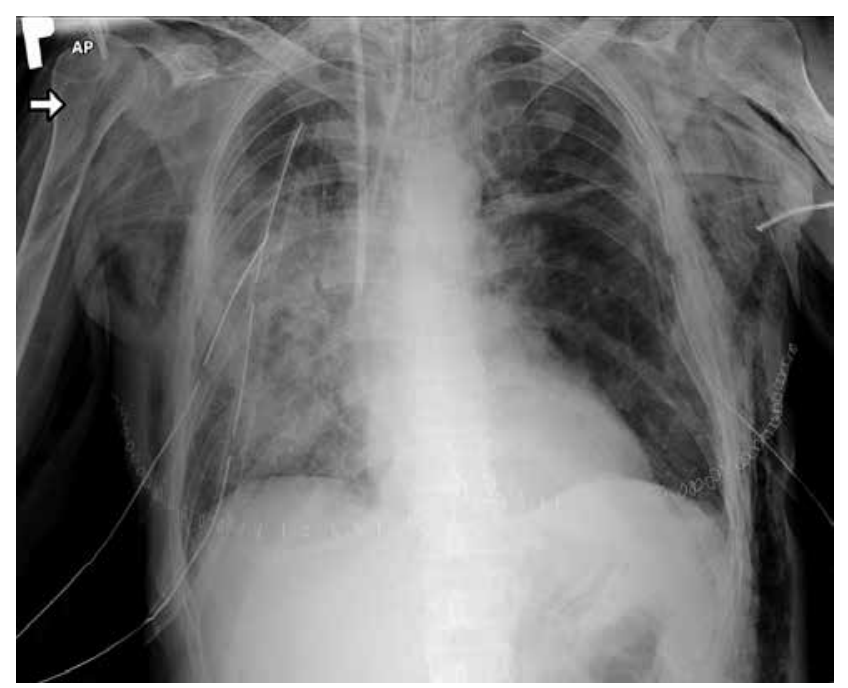

Fig. 2. Chest X-ray performed after lung volume reduction surgery (LVRS) 


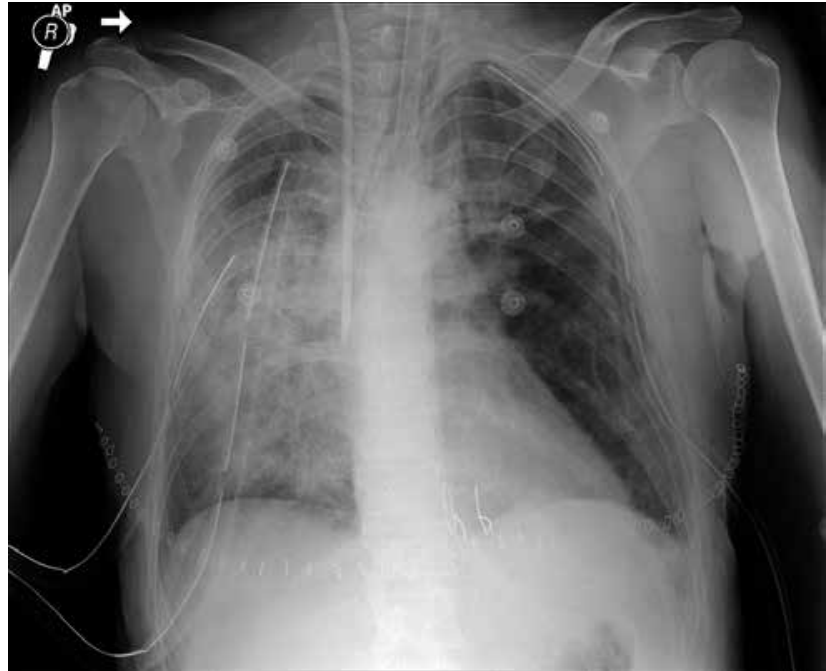

Fig. 3. Chest X-ray performed during first episode of acute rejection

coli urinary tract infection, both treated with amoxicillin and clavulanic acid, and a second episode of acute graft rejection. During the next two months $E$. coli sepsis was seen and was treated with ceftazidime. Then the cytomegalovirus disease treated with ganciclovir, pulmonary embolism, and anxiety disorder treated with opipramol and venlafaxine occurred. On account of leukopenia 2900/ $\mu$ l the pantoprazole and mycophenolate mofetil doses were reduced. After the next month the third episode of acute graft rejection appeared, following bacterial infection caused by Pseudomonas aeruginosa cured with ciprofloxacin and ceftazidime and bilateral otitis with sinus and temporal bone polyposis development, hence clindamycin and budesonide inhalation were applied. Because of hypogammaglobulinaemia it was decided to assign human immunoglobulins every three weeks. During the $11^{\text {th }}$ and $12^{\text {th }}$ month after the transplantation (Fig. 4) the next bacterial infections caused by Acinetobacter baumanii, Proteus mirabilis, Candida albicans, C. glabrata and Aspargillus species ensued. The therapy contained cefuroxime, imipenem, ampicillin with sulbactam, amikacin, amphotericin B, itraconazole, and colistin. Meanwhile drug-induced diabetes with rapid decompensation occurred, which initially needed glimepiride and then insulin therapy. Later, renal failure and a fourth episode of acute lung rejection appeared. Between the $14^{\text {th }}$ and $16^{\text {th }}$ month after lung transplantation the fifth episode of rejection appeared, renal failure deepened, and destabilisation of diabetes occurred. The cytomegalovirus disease activated and valganciclovir was used in therapy, but the leukopaenia deteriorated and it was necessary to reduce the dose of the drug. In addition, Acinetobacter baumani, Klebsiella pneumoniae, and Candida albicans infections appeared. In therapy the ceftazidime, ciprofloxacin, ampicillin with sulbactam, colistin, metronidazole, tazobactam, itraconazole, and nystatin were used. At this time anti-HLA antibodies were demonstrated (donor specific antibodies - DSA). Unfortunately, the psychological state of the patient gradually worsened, and she manifested symptoms

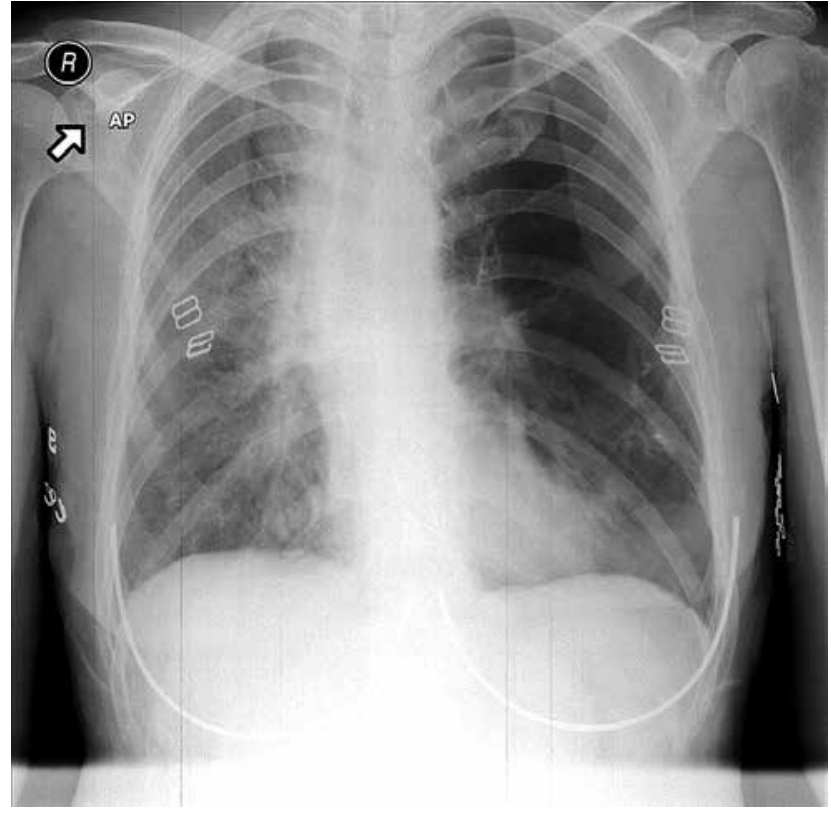

Fig. 4. Chest $\mathrm{X}$-ray performed one year after transplantation

of depression. After psychiatric consultation the therapy was completed with mianserin. Collateral complication appeared as posttraumatic haematoma of the shin, which required VAC-therapy (vacuum assisted closure - VAC). 498 days after transplantation the patient died due to symptoms of sepsis after unsuccessful reanimation.

\section{Discussion}

Lung transplantation in medically incurable patients is the only method that gives a chance to lengthen their lives. However, the selection criteria of donors and recipients should be tested and innovated. Retrospectively detected anti-HLA antibodies severely complicated the hospitalisation of the aforementioned patient. Currently it is recommended that the cross-match be pursued before performing the transplantation to avoid such a situation, although there are some scientific reports discussing the primary existence of these antibodies in the recipient's organism or their appearance as the consequence of transplanted organ dysfunction [2]. There are some case reports that adduce false positive and false negative pre-transplant virtual cross-matches [3]. However, virtual cross-match should be considered as a routine technique used before transplantation procedure in Poland. Virtual cross-match is the admitted method of prediction if the recipient produces HLAantibodies. An appropriate computer program determines every HLA antigen immunogenicity that is incompatible with full recipient HLA haplotype as an inconsistent immunogenic loci (miss-match amino acids eplets - mmEp). Safe immunogenic incompatibility that does not result in humoral response can also be predicted with this method. It is a huge advantage in patients who need multiple transplantations. Extending the scope of immunological selection to HLA-CW, DQ,DP increases the effectiveness of virtual cross-match (91\%) in comparison to serological selection 
on HLA-A,B,DR used in Poland [4]. Difficulties in proper donor selection are related with imperfection of chemical reagents and antibody detection techniques. In the first case the chance for transplantation is wasted, in the second the patient is exposed to serious postoperative complications. Furthermore, the role of antibodies against the host's own (personal) antigens in pathogenesis of chronic dysfunction of transplanted organs is discussed [5]. However, no matter which hypothesis is accepted, only quickly implemented therapy can improve the patient's condition. The choice of treatment is plasmapheresis. There are some ambiguous reports about monoclonal antibodies although there are some indications that such treatment can be effective $[6$, 7]. The aforementioned clinical report allowed many conclusions to be drawn. On this basis we proceeded with mandatory cross-match before lung transplantation in every recipient with PRA $>0 \%$. Also, the age of qualified donors is limited to 55 years old, whereas the criterion of $\mathrm{PaO}_{2} /$ $\mathrm{FiO}_{2}$ was raised to $>400 \mathrm{mmHg}$. The recommended operation technique is bilateral lung transplantation because of the reservoir of microorganisms in the recipient's own lung, so nowadays in such a clinical situation probably reconstruction of the donor's right pulmonary vein cuff would be performed [8]. Additionally, LVRS, according to present knowledge, would not be pursued, because the shading of the graft after transplantation was caused by primary graft dysfunction and not by the recipient's own lung. Finally, meticulous training of the transplantation team in surgical techniques should be continued, which is achieved in our case by practicing microsurgical techniques on rats and by using a cadaver workshops.

\section{Disclosure}

Authors report no conflict of interest.

\section{References}

1. Lund LH, Edwards LB, Kucheryavaya AY, Dipchand Al, Benden C, Christie JD, Dobbels F, Kirk R, Rahmel AO, Yusen RD, Stehlik J; International Society for Heart and Lung Transplantation. The Registry of the International Society for Heart and Lung Transplantation: Thirtieth Adult Lung and Heart-Lung Transplant Report - 2013; focus theme: age. J Heart Lung Transplant 2013; 32: 965-978.

2. Platt JL, Cascalho EM. Donor specific antibodies after transplantation. Pediatr Transplant 2011; 15: 686-690.

3. Jacob EK, De Goey SR, Gandhi MJ. Positive virtual crossmatch with negative flow crossmatch results in two cases. Transpl Immunol 2011; 25: 77-81.

4. Zielińska H, Moszkowska G, Dębska-Ślizień A, Zieliński M, Jankowska M, Rutkowski B, Trzonkowski P. Możliwości diagnostyczne oceny ryzyka immunologicznego biorcy nerki przed przeszczepieniem i po jego wykonaniu. Forum Nefr 2011; 4: 320-330.

5. Witt CA, Hachem RR. Current perspectives on antibody-mediated rejection after lung transplantation. Transplant Research and Risk Management 2014; 6: 109-115.

6. Scheffert JL, Raza K. Immunosuppression in lung transplantation. J Thorac Dis 2014; 6: 1039-1053.

7. Otani S, Davis AK, Cantwell L, Ivulich S, Pham A, Paraskeva MA, Snell GI, Westall GP. Evolving experience of treating antibody-mediated rejection following lung transplantation. Transpl Immunol 2014; 31: 75-80.

8. Lau CL, Patterson GA. Technical considerations in lung transplantation. Chest Surg Clin N Am 2003; 13: 463-483. 